\title{
Dijital Aktivizmde Ünlüller: Ahbap Platformu Üzerine Bir Değerlendirme
}

\section{Celebrities in Digital Activism: An Evaluation of 'Ahbap Platformu'}

\author{
Ebru GÖKALİLER ${ }^{1 \oplus}$, Ezgi SAATCIOĞLU ${ }^{2 \oplus}$
}

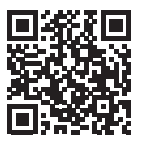

${ }^{1}$ Assoc. Prof. Dr, Yaşar University, Faculty of Communication, Department of Public Relations and Advertising, İzmir, Turkey 2PhD., Yaşar University, Graduate School of Social Sciences, İzmir, Turkey

ORCID: E.G. 0000-0002-4134-8447; E. S. 0000-0003-3108-0579

Sorumlu yazar/Corresponding author: Ebru Gökaliler,

Yaşar Üniversitesi, Illetişim Fakültesi Halkla İlişkiler ve Reklamcılık Bölümü, İzmir

E-posta/E-mail: ebru.gokaliler@yasar.edu.tr

Geliş tarihi/Received: 07.01.2019 Revizyon talebi/Revision Requested: 11.02.2019

Son revizyon teslimi/Last revision received: 24.05 .2019

Kabul tarihi/Accepted: 27.05.2019

Atıf/Citation: Gokaliler, E., \& Saatcioglu, E. (2019). Dijital aktivizmde ünlüler: ahbap platformu üzerine bir değerlendirme. Connectist: Istanbul University Journal of Communication Sciences, 56, 87-117. https://doi.org/10.26650/CONNECTIST2019-0003 öz

Ünlüler, aktivist bir amaçla eşleştirilerek sahip oldukları geniş kitlelere seslenme gücüyle toplumda farkındalık yaratma, harekete geçirme sağlayarak aktivist bir kimlik edinebilmektedir. Bu betimleyici çalışma; ünlülerin, aktivist kimliklerini sosyal medya hesaplarına yansıtarak geniş kitlelere ulaşabildikleri temeline dayanmaktadır. Çalışmanın amacı; ünlülerin aktivist çalışmalarını, aktivist kimliklerini kendi sosyal medya hesaplarına yansıtmalarını ve oluşturulan özel platformları incelemektir. Araştırmada, aktivist bir sanatçı olarak değerlendirilen Haluk Levent'in resmi Twitter hesabı ve Ahbap Platformu ekseninde amaçsal örneklem yöntemiyle incelenmektedir. Örneklemin seçiminde Haluk Levent'in yardımsever ünlü kimliğiyle giderek artan popülerliğine bağlı olarak Twitter'da artan erişim kitlesi etkili olmuştur. İçerik analizi tekniğinden yararlanılan analiz, 15.10.2018-15.12.2018 olarak sınırlandırılmıştır. Araştırma sonucunda Haluk Levent'in resmi Twitter hesabında yer alan tweetlerin büyük oranda kendi hesabından gönderildiği; retweetlerin çoğunluğunun Ahbap Platformu'ndan olduğu görülmektedir. Bu bağlamda dernek gönüllülerinin çalışmalarını öne çıkardığı ve ünlü kimliğiyle dernek çalışmalarını eşleştirmeye çalıştığı söylenebilmektedir. Twitter gönderilerinde yüksek oranda görsellerden yararlanılmaktadır. Farklı toplumsal konulardaki paylaşımlar arasında en yüksek oranda gönderinin 'Sağlık' konusunda olduğu görülmektedir. Gönderilerdeki metin tonununsa hem aktivizme yönelik hem de aktivizm dışı içeriklerde çoğunlukla samimidir. Ünlü aktivizmi modeline göre Twitter'da 'Sözcü' kategorisinde ünlü aktivizmi gerçekleştirdiği saptanmıştır.

Anahtar Kelimeler: Dijital aktivizm, ünlü aktivizmi, sosyal medya aktivizmi, sosyal medyada ünlü aktivizmi, Twitter 


\begin{abstract}
With the power to speak to a wide audience celebrities can create an awareness in society and mobilization can be ensured by transfering meaning between celebrity identity and an activist purpose. This study is based on the fact that celebrities' ability to access a wide audience by channeling their activist identity through their social media accounts. This study aims to examine how celebrities reflect their activist efforts and identities in their social media accounts. Haluk Levent's official Twitter account, who's been considered as an activist celebrity, is examined using the purposive sampling. This sample was chosen because of his popularity due to celebrity activism, and his
\end{abstract}

growing ability to reach more people. The content analysis technique was used. The analysis was limited to the period between 15.10.2018-15.12.2018. As a result of the study, the majority of the retweets belong to the 'Ahbap Platformu'. In this context, he highlights the work of volunteers, associating his personal brand and the organization. He has tweeted about various social issues, notably 'Health'. The tone of the text appears to be mostly warm in both the activist and non-activist content. According to the celebrity activism model, his Twitter activism can be categorized as 'Spokesperson'.

Keywords: Digital activism, celebrity activism, social media activism, celebrity activism on social media, Twitter

\section{EXTENDED ABSTRACT}

Cammaerts (2007, p. 217) defines activism as the ability to create or change history. Digital technologies help to create a new channel for activism. Internet activism or rather, social media activism, is a sub-type of digital activism. According to the literature there are certain types of digital activism such as slacktivism, clicktivism, and hacktivism. Considine (2003, p. 134) refers to two types of digital activism strategies. The first one supports real life activism via digital content, and the second one is content created by activists just for the digital media and the Internet. Celebrities have been important figures in activism for a long time. Celebrity activism can be seen as the celebrity endorsement strategy of non-governmental organisations. Celebrities can be helpful for different issues such as raising awareness, fundraising, etc. However, if the celebrity activism and the celebrity involved in the cause are not sincere then this strategy does not work well. Celebrity activism is associated with role modeling, and McCracken's meaning transfer model. According to McCracken's (1989) meaning transfer model, consumers have certain perceptions of celebrities and those perceptions are transfered to the brand through celebrity endorsement. This also works for non-governmental organisations and social causes. Huddart (2005) developed a model for celebrity and civil society engagement. According to his model there are 4 types of celebrities in activism, namely; Patron, Spokesperson, Ambassador/Author, and Visionary Leader. Digital technologies are now serving as a new tool for activism. They are also serving as a new tool for celebrity 
activism. Being a celebrity can only be possible through constant interaction with the public, and social media provides a good channel for interaction. Celebrities can join activist movements via their social media accounts by tweeting, using hashtags, etc. or they can start their own. Moreover, celebrities have a chance to reach a wider audience on their social media accounts.

This study aims to examine celebrities' reflections of their activist efforts and their activist celebrity identities on their social media accounts. In line with this objective, Haluk Levent's (a Turkish singer) official Twitter account was examined using purposive sampling. There are multiple reasons for this choice of celebrity. First of all, Haluk Levent's popularity has increased through his celebrity activist image. Secondly, it is seen that his number of Twitter followers is increasing steadily. This can be interpreted as his growing ability to reach more people, and to be reached by more people. The analysis was conducted using the content analysis technique. The analysis was limited to the period between October 15, 2018 and December 15, 2018. In total, 513 posts were examined.

As a result of the study, it was determined that the majority of the posts belonged to the official Twitter account and $8.1 \%$ of the posts were retweets. The majority of the retweets belonged to the non-governmental organization established by Haluk Levent. This can be interpreted as his efforts to focus attention on his organization and the efforts of volunteers. The majority of the tweets had visual content. Visuals are considered as helpful tools to attract followers' attention. The majority of the tweets were related to 'Health' issues, followed by 'Donations and Scholarships'. When the text tone was examined it was seen that a warm tone was used in both activist content and non-activist content. This can be interpreted as him attempting to establish intimacy with his followers and to encourage them to work cooperatively. Finally, according to the celebrity activism model and his Twitter usage, he can be categorized as a 'Spokesperson'.

As a result, it can be said that the findings of the content analysis are consistent with the literature. First of all, he is known as a person who supports social aid on social media, and this is supported by his tweets. In the literature it is said that being a celebrity relies on the interaction and intimacy between the celebrity persona and the audience. This also applies to celebrity activism. His Twitter usage shows just such an example of establishing intimacy between the celebrity, audience, and activism. 


\section{GíRiş}

Aktivizm temelde bireylerin veya çeşitli kuruluşların toplumsal sorunlara eğilmelerini ve çözüm arayışlarını ifade etmektedir. Dijital teknolojilerin giderek yaygınlaşması ile aktivizm, dijital ortama da taşınmaktadır. Dijital medya aktivizminin bir alt türü olan sosyal medya veya internet aktivizmi, her bireye aktivist olma fırsatı sunmaktadır. İmza kampanyalarına katılmak, bağışta bulunmak, çeşitli platformlar üzerinden beğeni, yorum veya paylaşımlarda bulunmak sosyal medya temelinde dijital aktivizm çerçevesinde değerlendirilmektedir. Özellikle Twitter, aktivist çalışmalar için değerlendirilen bir sosyal medya platformudur. Platformda 'hashtag'ler aracılığıyla dahi gündem oluşturulabilmekte, yardıma intiyaç duyanların sesleri duyurulabilmekte ve birtakım yardım faaliyetleri gerçekleştirilebilmektedir. Bu faaliyetlerin fiziksel ortama taşınmaması halinde 'tembel eylemcilik', 'tıklama eylemciliği' olarak da ifade edilmektedir. Bununla birlikte sosyal medyada bir araya gelen grupların gerçek yaşamda da bir araya gelerek aktivist etkinlikler gerçekleştirdikleri görülmektedir. Dijital aktivizm; bireyler veya sivil toplum kuruluşları tarafından gerçekleştirilebilmektedir. Kimi örnekler de ise ünlülerin de dijital aktivist hareketlere katıldıkları veya bu hareketleri düzenleyenler oldukları görülmektedir.

Ünlü aktivizmi kavramı; ünlülerin, toplumsal amaçlar için çalışmalarını ifade etmektedir. Geleneksel anlamda ünlü aktivizminde ünlüler, çeşitli toplumsal amaçların veya kuruluşların sözcüsü haline gelebilmektedirler. Ünlüler, kar amaçlı kuruluşların sosyal sorumluluk faaliyetleri kapsamındaki kampanyaların parçası olabilecekleri gibi sivil toplum kuruluşlarının gerçekleştirdikleri kampanyaların da parçası olabilmektedirler. Bu faaliyetlerin yanı sıra ünlüler, bireysel olarak da toplumsal amaçlar için çalışabilmektedirler. Ünlü aktivizminde önemli noktalar ise ünlünün güvenilirliği ve ilgili toplumsal amaçla uyumlu olmasıdır. Böylelikle ünlü ile toplumsal amaç arasında kurulan anlam aktarımı ile toplumun ilgili toplumsal amaca yönelik farkındalıkları ve verdikleri önem arttırılabilmektedir. Ünlülerin sahip oldukları hayran kitleleri de aktivist faaliyetler açısından önem taşımaktadır. Çünkü hali hazırda ünlünün hayranı olan kişiler, ünlünün savunduğu toplumsal amaçların savunucusu haline gelebilmektedirler. Öte yandan bir ünlünün savunucusu olduğu toplumsal amaçlar da onun ününe ve ünlü kimliğine katkı sağlayabilmektedir. 
Aktivizmin dijitale taşınmasının ünlü aktivizmi açısından da geçerli olduğu görülebilmektedir. Bu bağlamda ünlüler, Twitter başta olmak üzere sosyal medya hesaplarında gerçekleştirdikleri paylaşımlar aktivist faaliyetler gerçekleştirebilmektedirler. Geniş kitlelere ulaşabilen ünlüler bu bağlamda farkındalık yaratabilmekte, yardım kampanyaları düzenleyebilmektedirler. $\mathrm{Bu}$ faaliyetler, belirli bir olay üstüne gerçekleştirilebildiği gibi uzun döneme yayılarak belirli bir ünlünün kimliğinin parçası haline de gelebilmektedir. Bu bağlamda ünlülerin sosyal medyada sahip oldukları aktivist potansiyelden yola çıkılarak bu çalışmada aktivist ünlülerin, gerçekleştirdikleri faaliyetleri kendi sosyal medya hesaplarına nasıl yansıttıklarının incelenmesi amaçlanmaktadır.

Bu amaç doğrultusunda örnek olay incelemesi kapsamında Haluk Levent'e ait resmi Twitter hesabı ele alınmaktadır. Haluk Levent, aktivist bir ünlü olarak gerçekleştirdiği yardım faaliyetleri ile hem geleneksel medyada hem de sosyal medyada sıklıkla yer almaktadır. Ayrıca kurmuş olduğu dernekte de gönüllüler aracılığıyla pek çok faaliyet gerçekleştirilmektedir. Bu bağlamda Haluk Levent'in aktivist sanatçı kimliğinin kendi Twitter hesabına yansıyıp yansımadığı, yansıyorsa ne şekilde gerçekleştiği irdelenmektedir. Araştırmada, içerik analizi tekniğinden yararlanılmıştır. 15 Ekim 2018 - 15 Aralık 2018 tarihleri arasında Haluk Levent'in resmi Twitter hesabında paylaşılan gönderilerin içerik analizleri gerçekleştirilmiştir. Gönderilerin; tweet, retweet, yorum, beğeni dağılımları ile gönderilerin konulara göre dağılımları incelenmiştir. Gönderilerin metin tonu incelenmiş son olarak ise gönderiler, ünlüler ve sivil toplum etkileşimi modelin çerçevesinde analiz edilmiştir.

\section{Dijital Aktivizm}

Oxford İngilizce Sözlüğü'ne göre aktivizm; siyasi veya sosyal değişim yaratmak üzere gerçekleştirilen etkinlikler veya benimsenen politikalar olarak tanımlanmaktadır ("Activism", n.d.). Bir diğer tanımda ise aktivizm; tarih yaratma veya değiştirme yeteneği olarak yer almaktadır (Cammaerts, 2007, p. 217). Dijital teknolojilerin ve bu bağlamda sosyal medyanın sağladığı iletişim ve koordinasyon olanakları onu aktivizm için önemli hale getirmektedir (Denning, 2001, p. 242). Aktivizm çerçevesinde dijital teknolojilerden yararlanılması, dijital aktivizm olarak adlandırılmaktadır (Sivitanides \& Shah, 2011, p. 2). Dijital aktivizm, bireylerin çeşitli siyasal ve toplumsal konulardaki görüşlerini dijital ortama taşıyarak eylemleştirmelerini ifade etmektedir. Dijital aktivizmde, dijital teknolojiler, özellikle de internet teknolojisi önem taşımakta olup bu bağlamda geniş kitlelere hızlı bir biçimde ulaşılabilmektedir (Yegen, 2014a, p. 89). 
Internet aktivizmi bir diğer deyişle sosyal medya aktivizmi, dijital aktivizmin bir türü olarak ele alınmaktadır (Van Laer \& Van Aelst, 2010, p. 1148). Literatürde ayrıca dijital aktivizmle ilişkili olan slaktivizm, kliktivizm, hacktivizm kavramları da yer almaktadır. Hem kliktivizm yani tıklama aktivizmi hem de slaktivizm yani tembel aktivizm; aktivist hareketlere fiziksel olarak değil, dijital teknolojiler ve sosyal medya aracılığıyla katılmayı ifade etmektedir (Yılmaz, Dündar \& Oskay, 2015, p. 491; Rotman et al. 2011). Bununla birlikte kliktivizm ve slaktivizm arasında birtakım farklılıklar bulunmaktadır. Kliktivizm, yönetimsel bir nitelik taşımaktadır. Kliktivistler, kampanyaları başlatarak kitleleri biraraya getirmektedir. Slaktivizm ise kampanyalara sosyal medya üzerinden destek vermeyi ifade etmektedir (Yegen, 2014b, p. 122). Bu bağlamda kliktivistler; kampanyaları oluşturan, yöneten ve sürdürenlerken slaktivistler ise kampanyalara sosyal medya üzerinden destek verenlerdir. Hackleme ve aktivizm kavramlarının birleşimiyle meydana gelen hacktivizm ise çoğunlukla yasal olmayan ve izinsiz bir biçimde bilgisayar sistemlerine sızmayı ifade etmektedir (Denning, 2001, p. 263).

Dijital aktivizmin doğrudan ve dolaylı olmak üzere birtakım araçları bulunmaktadır. Dijital aktivizmin doğrudan araçları arasında internet siteleri, hacktivizm, zincir e-postalar yer alırken dolaylı araçları arasında ise sosyal medya platformları ve çevrimiçi imza kampanyaları yer almaktadır (Yılmaz et al., 2015, pp. 488-490). Considine (2003, p. 134) dijital aktivizmin ve internet aktivizminin stratejilerini iki temel kategoride ele almaktadır. Bu stratejilerden ilki; gerçek yaşamdaki aktivitelerin, internetteki aktiviteler tarafından desteklenmesidir. Bu stratejiye göre sosyal medya platformları ve içerikler, gerçek yaşamdaki etkinliklerin düzenlenmesinde yani duyuru, bilgilendirme, organizasyon amacıyla kullanılmaktadır. İinci strateji ise aktivist grubun kendi adına oluşturduğu içerik bağlamında internet aktivitesi olmaktadır. Bu stratejide, tüm etkinlik internet üzerinde gerçekleşmektedir. Bu duruma örnek olarak çeşitli viral kampanyalar ve hacktivizm verilebilmektedir. Denning (2001, pp. 243-263) ise dijital medyayı aktivizm çerçevesinde değerlendiren 5 yöntem bulunduğunu ifade ederek bu yöntemleri; koleksiyon, yayım, diyalog, eylemin koordinasyonu, lobicilik olarak sıralamaktadır (Kvansny, Payton \& Hales, 2010, pp. 21-22):

Koleksiyon: İnternet, devasa bir dijital kütüphane olarak ele alınmaktadır. Bu kütüphanede gerçek enformasyonun depolanmasının yanı sıra üye kazanma, bağış toplama, organizasyon gibi pek çok etkinliğin gerçekleştirilmesine yarayan bir rehber olarak da hizmet sunmaktadır. 
Yayım: Internet, bireylerin ve toplulukların enformasyon yayımlamalarına ve yaymalarına yardımcı olmaktadır. E-posta gönderimlerinden, haber grupları veya mesaj panolarına yapılan gönderilerden, bloglar veya internet sitelerinde üretilen içeriklerden yararlanılarak bireyler bir araya toplanabilmekte, potansiyel destekçilerle enformasyon paylaşılabilmektedir. Bu noktada dijital medyanın, geleneksel medyadan daha düşük maliyetli olması da önem taşımaktadır.

Diyalog: Internet, ilgilenilen konuya ilişkin kamusal düzeyde veya özel düzeyde diyaloglar için sosyal bir mekan olarak değerlendirilmektedir. E-posta ve haber grupları, forumlar gibi çeşitli yollarla sağlanabilmektedir.

Eylemin Koordinasyonu: Gerçekleştirilecek etkinliklere ilişkin paylaşımların yapıldığı, karar alma sürecinin gerçekleştirildiği bir araç olarak dijital platformlardan yararlanılmasıyla dünya çapında koordinasyon sağlanmaktadır.

Lobicilik: Otorite sahiplerine ulaşabilmek ve onları etkileyebilmek amacıyla e-posta protestoları, imza kampanyaları düzenlenebilmektedir.

Dijital araçların özellikle de sosyal medyanın aktivist amaçlarla kullanılmasında içsel ve dışsal roller bulunmaktadır. İçsel roller; aynı amaçlara sahip bireylerin kendi içlerinde gerçekleştirdikleri tartışmalar ve karar alma sürecinden oluşurken dışsal roller; harekete geçme, insanları bir araya getirme, iletişim kanalları oluşturma şeklindedir. Dijital teknolojiler, bu rollerin gerçekleştirilmesinde zaman ve mekan bağımlıığını ortadan kaldırmaktadır (Cammaerts, 2015, p. 1029).

\section{Ünlü Aktivizmi ve Sosyal Medyada Ünlü Aktivizmi}

Ün ve ünlü kavramları kültürel birer yapıdır (Marwick \& Boyd, 2011, p. 140). Ünlü kavramı, Turner $(2013$, p. 23) tarafından bir sektörün kontrolü altındaki medya süreci olarak tanımlamakta olup ünlünün, izleyiciler veya hayranlar tarafından tüketilen bir ürün olduğunu vurgulamaktadır. Bu bağlamda Turner, ünlü kavramına yönelik 3 tanımlamaya dikkat çekmektedir. Bunlardan ilki; insanların sunulma ve konuşulma biçimiyken ikincisi ise bir kişinin metaya dönüşümü olmaktadır. Bir diğer tanımlamaya göre ise ünlü, sürekli olarak değişen bir kültür ürünü olarak ifade edilmektedir (Marwick \& Body, 2011, p. 140). Günümüzde ünlü olmak, farklı biçimlerde ve derecelerde gerçekleşmektedir. Kimi ünlüler medyada yüksek 
görünürlüğe sahip olup uluslararası düzeyde tanınırken kimi ünlüler ise ulusal veya yerel düzeyde tanınmaktadırlar. Kimi ünlüler ise ünlerini sosyal medyadan almaktadırlar (Jeffreys \& Allatson, 2015, p. 6). Huijser \& Tay (2011, p. 109) ünlülerin başlı başına bir ürün olarak görülmelerinin onlara değer kattığını ifade etmektedir. Bu bağlamda farklı politik amaçların sesi olma ve aktivizm için değerli hale de gelmektedirler. Bu değeri sürdürebilmek ise sahip oldukları ünü sürdürmekten geçmektedir.

Ünlüler, yer aldıkları pazarlama kampanyalarında ürünlerin ve hizmetlerin tanıtımını ve satışını sağlayabildikleri gibi düşüncelerin de yayılmasına ve bir anlamda satılmasına yarar sağlayabilmektedirler (Cooper, 2008, p. 10). Örneğin, Michael Jackson Pepsi reklamlarında oynadığı gibi Band Aid'in We are the World (1985) parçasının yaratımında da yer almıştır (Bulck \& Panis, 2010, p. 242). Ünlüler, birer rol modeli olarak görülebildikleri için bu anlamda başta hayran kitleleri olmak üzere toplumu etkileyebilmektedirler (Hanna, Kantenbacher, Cohen, \& Gössling, 2018). Ünlülerin rol modeli olarak alınması, McCracken'ın (1989) anlam aktarımı modeli ile açıklanmaktadır. Bu modele göre tüketicilerin belirli bir ünlü hakkında sahip oldukları algılar, ünlü kullanımının gerçekleştirilmesi ile reklamı yapılan ürüne aktarılmaktadır. Benzer bir durum düşüncelerin satışında yani aktivist hareketler içerisinde de gerçekleşmektedir. Günümüzde ünlüler çeşitli sivil toplum örgütlerinde ve Birleşmiş Milletler gibi uluslararası örgütlerde sözcüler olarak öne çıkmaktadırlar. Bunu yanı sıra ünlüler, sahip oldukları takipçi ve hayran kitlesi sayesinde kendi aktivist çalışmalarını da gerçekleştirebilmektedirler (Budabin, 2015, p. 401). Yang, Zhou ve Zhang (2018, pp. 3, 12) ise ünlü aktivizminin medya yansıması ve hayran tabanı olmak üzere iki temel karakteristiğinin bulunduğunu belirtmektedirler. Ünlünün sahip olduğu ünü medyada yer alarak farkındalık yaratmak ve dikkat çekmek için kullanılabilirken diğer yandan ünlülerin hayranları tarafından rol modeli olarak görülmeleri nedeniyle onlar üzerinde etki sahibi olabilmektedirler. Jeffreys (2016, p. 772) ünlülerin sözcüsü olduğu kampanyalarda rol modelleri aracılığıyla ahlaki açıdan bir ikna çalışması gerçekleştirildiğini ifade etmektedir. Özellikle çevre odaklı kampanyalarda gençler üzerinden bireysel davranışların değiştirilmesine yönelik çalışmalar yürütüldüğünü vurgulamaktadır. Bununla birlikte Hassid ve Jeffreys (2015) Çin'de gerçekleştirdikleri araştırma sonucunda sivil toplum örgütlerinin ünlülerle gerçekleştirdikleri işbirliğinin, etkinliklerinin medyaya yansıması üzerinde çok az etkisi olduğunu ortaya koymaktadırlar. 
Seçilmiş politikacıların veya adayların, görüşlerini ve iddialarını savunabilmek için tanınmış kişiler olarak medyada yer almaları ve ün kazanmaları gerekirken popüler kültürün bir parçası olan ünlüler ise seçilmiş politikacılar olmadıkları için politik alandaki meşruiyetlerini medya ve izleyiciler yoluyla sağlamaktadırlar (Street, 2004, p. 435). Bu bağlamda ünlüler arasında rekabet yaşandığı da görülmektedir. Duvall (2015, p. 584), 2010'da Haiti'de yaşanan deprem sonrası yardıma giden Wyclef Jean ve Sean Penn arasında uluslararası medya aracılığıyla rekabete dayalı bir anlatı oluşturulduğunu ifade etmektedir. Huliaras ve Tzifakis (2010, pp. 259-261), ünlü aktivizminin giderek artmasına ilişkin 3 dışsal ve 2 kişisel etkenden söz etmektedir. Dışsal etkenler; Birleşmiş Milletler, sivil toplum örgütleri ve ünlülerin geçmişte olduğundan daha özgür bir biçimde hareket etmeleri olarak sıralanmaktadır. Kişisel etkenler ise ünlülerin, ünlerini koruyabilmek adına aktivist hareketlerde bulunmaları ve ünlülerin diğer ünlüleri harekete geçirme özelliklerinin bulunması olarak sıralanmaktadır. Bununla birlikte Hart ve Tindall $(2009$, p. 11) ünlülerin, yalnızca bir imaj çalışması için gelip geçici olarak aktivist çalışmalar gerçekleştirmelerinin tepki çektiğini belirtmektedir (Hart \& Tindall, 2009).

Ünlü aktivizminde, ünlünün güvenilirliği önem taşımaktadır. Bu bağlamda ünlünün güvenilirliği, savunulan amaç ve varsa ünlü ile çalışan sivil toplum örgütü açısından önem taşımaktadır. Franklyn (2016, p. 32) ünlülerin aktivist mesajlarının güvenilirliğine değinmekte olup çalışmasında ünlülerin verdiği mesajların, ünlü olmayanların verdiği mesajlardan daha güvenilir olduğunu ortaya koymaktadır. Bir diğer önemli unsur ise ünlüyle kurulan yakınlık olmaktadır. Ünlüler, hayranlar ve izleyiciler arasında belirli bir toplumsal mesafe bulunmakta (Rojek, 2001, p. 12) ve ünlü olmak bir tür statü sistemi olarak da ele alınmaktadır (Milner, 2010). Fuqua (2011, p. 193) Katrina Kasırgası sonrasında Brad Pitt'in New Orleans'ta yaptığı çalışmalar, ünlü aktivizmi çerçevesinde değerlendirmektedir. Brad Pitt'in geleneksel anlamda sahip olduğu "ünlü", "yıldız" kimliklerinin Katrina sonrası süreçte yeniden inşa edilerek toplumsal açıdan halka daha yakın bir ünlü kimliği inşa edildiğini belirtmektedir. Haluk Levent, aktivist bir ünlü olarak da Türkiye'deki toplumsal olaylara ve yardıma ihtiyacı olan bireylere yönelik yardım faaliyetleri gerçekleştirmektedir. Aynı zamanda bu yardım faaliyetlerini başlatarak daha da geniş kitlelerin harekete geçmesi için çalışmaları geleneksel medya ve geleneksel olmayan medyada duyurmaktadır. Sosyal medya hesabının takipçi sayısı her geçen gün artmakta ve içerikleri ve paylaşımları takipçileri tarafından etkileşim yaratmaktadır. Bu bağlamda sadece kendi sayfasından değil, yardımları 
duyurma ve yardımlaşma amacıyla kurduğu Ahbap Platformu aracılığıyla da pek çok etkinlik düzenlemekte, yardım gerçekleştikten sonra da onları yalnız bırakmayarak yanlarında olmaktadır. Haluk Levent hem ünlü olarak hem de aktivist olarak medyanın gündeminde yer almaktadır. Sanatçı kimliğini yardımlaşmayla birleştirerek yardım konserleri vb konularda aktivist kimliğiyle kesişme noktaları bulmaktadır.

Ünlü aktivizminin çeşitli etkileri bulunmaktadır. Ünlüler, halkın ilgisinin çekilmesine yardımcı olmaktadırlar. Bununla birlikte ünlülerin kampanyanın önüne geçmesi yalnızca medya içeriği oluşturulmasına ve kampanyanın öneminin göz ardı edilmesine yol açabilmektedir. Ayrıca ünlüler hem kendi yaptıkları bağışlarla hem de yüzü oldukları kampanyalarda bağış toplanmasına destek olarak bağış ve fonlama üzerinde etkili olmaktadırlar. Bununla birlikte lobicilik faaliyetlerinde yeterli başarıyı gösterememektedirler (Huliaras \& Tzifakis, 2010, pp. 262-263). Ünlülerin daha yüksek gelir düzeyine sahip olmaları, daha yüksek oranda bağış yapmalarını sağlamaktadır (Yang et al., 2018, p. 12). Pek çok ünlü, yardım faaliyetlerine ve derneklere destek verirken kimi ünlüler ise belirli bir sorun veya amaç için topluma liderlik etmektedirler. Bu bağlamda siyasi süreçte yer alabilmek için de çabalamaktadırlar. Bununla birlikte sözcülük ve bağış yapmak liderlik için önemli olsa da yeterli olmamaktadır. Ünlülerin başarılı liderler olabilmeleri için hedef kitlelerinin ilgisini çekmeleri ve onları amaca bağlamaları gerekmektedir (Hart \& Tindall, 2009). Ayrıca, belirli bir ünlüye bağlılık duyan hayran toplulukları da kendi aktivist çalışmalarını gerçekleştirebilmektedir (Jeffreys \& Xu, 2017). Bu duruma örnek olarak hayranların, hayranı oldukları ünlünün adına çeşitli kuruluşlara bağış yapmaları verilebilmektedir.

Huddart (2005) ünlüler ve sivil toplum etkileşimine ilişkin bir model ortaya koymaktadır. Bu modele göre düşük, orta, yüksek ve dönüştürücü olmak üzere 4 etkileşim düzeyi bulunurken ünlüler; düşük etkileşim düzeyinde koruyucu, orta etkileşim düzeyinde sözcü, yüksek etkileşim düzeyinde elçi/yazar, dönüştürücü düzeyde ise vizyoner lider olmaktadırlar. Ayrıca farkındalık yaratmak, fonlama ve savunma olmak üzere 3 temel etkinlik alanı bulunmaktadır (Andersson, 2007, pp. 31-33):

Koruyucu: Ünlünün ismi, sivil toplum örgütü tarafından güvenilirlik sağlamak amacıyla kullanılmaktadır. Bu düzeyde ünlü; basın açıklamalarını imzalayarak destek olmakta ve kişisel bağışta bulunmaktadır. 
Sözcü: Bu düzeyde ünlü, belirli bir yardım kuruluşu veya sivil toplum örgütü ile eşleştirilmektedir. Çeşitli etkinliklere katılarak sözcüsü olduğu sivil toplum örgütü adına açıklamalarda bulunmaktadır. Sözcüler, sivil toplum örgütlerinin yönetim kurulunda yer alabilecekleri gibi kendi çabaları ile kendilerine ait yardım örgütleri kurabilmektedirler.

Elçi/Yazar: Bu düzeyde ünlüler, bir toplumsal amaç için kitap yazabilmektedirler. Elçiler; bağış toplama etkinliklerine ve turlarına katılmakta, lobicilik yapmakta, siyasilerin kampanyalarına katılmakta ve çeşitli hareketlerin liderleri olarak öne çıkmaktadırlar. Konuya ilişkin filmlerde veya belgesellerde yer alabilmektedir.

Vizyoner Lider: Vizyoner liderler, elçilik görevlerini olağanüstü bir çaba ile gerçekleştiren ünlüler olmaktadır. Küresel boyutta televizyonda yayınlanan konserler organize etmek, bağış toplamak üzere televizyon programları düzenlemek vizyoner liderlerin etkinlikleri arasında yer almaktadır.

Ünlü aktivizmine yönelik olumlu ve olumsuz yaklaşımlar bulunmaktadır. Olumlu yaklaşım; ünlü aracılığıyla insani değerlerin, dünya vatandaşı olmanın popülerleştirildiğini ve öne çıkarıldığını savunmaktadır (Bishop \& Green, 2008). Scott (2011) ise ünlü aktivizminin, popüler kültür içinde dönüşüme uğramış bir balondan mı ibaret olduğunu tartışmaktadır. Ona göre ünlülerin başı çektiği aktivist hareketler, örneğin Live Aid gibi organizasyonlar, popüler kültür ürünleri haline gelmektedir. Afrika'daki açlığa dikkat çekmek ve harekete geçmek için düzenlenen Live Aid, Afrika'daki açlığa karşı etkin çözümler sunmazken konserlerin gerçekleştiği şehirler, katılan ünlüler, organizatörler, sponsorlar etkinliğin olumlu imajından ve ekonomik getirisinden yararlanmaktadırlar (Davis, 2010, p. 96). Ünlü aktivizmine yönelik bir diğer eleştiri ise ünlülerin savundukları amaca yönelik gerekli bilgiye sahip olmamalarıdır. Bu duruma örnek olarak George Clooney'nin Darfur'daki savaşa müdahale edilmesi için yürüttüğü kampanyanın olası farklı sonuçlarını öngörememesi verilmekte iken medyada yer almanın her zaman olumlu bir biçimde gerçekleşmemesine örnek olarak ise Live Earth konserinden önce Akon'ın basına, daha önce 'yeşil olma' kavramının ne anlama geldiğini bilmediğini açılaması verilmektedir (Jampolsky, 2012, pp. 232-233). Bu bağlamda ünlü aktivizmi bilinmeye ve tanınmaya dayanmakla birlikte her zaman yüksek düzeyde kalifiye olmamaktadır (Hart \& Tindall, 2009).

Ünlü aktivizmi geçmişte de var olmakla birlikte günümüzde değişen teknoloji ve medya ile yeni bir boyuta taşınmaktadır (Andersson, 2007, p. 10). Haluk Levent sanatçı 
kimliği ile bilindiğinden bu yana her zaman toplumda ihtiyaç sahiplerine yönelik duyarlılık göstermiş olmasına karşın sosyal medya aracılığıyla daha hızlı ve kısa sürede geniş kitlelere ulaşabilmeyi başarmaktadır. Ünlülük durumu, ünlü olan kişi ve hayranları arasındaki sürekli etkileşime bağlı olmaktadır (Marwick \& Boyd, 2011, p. 145). Ünlü aktiviziminde de ünlü kişi ile bir bağ kurulması önem taşımaktadır. Sosyal medya, ünlü aktivizmi için yeni olanaklar sunmaktadır (Ellcessor, 2018, pp. 266-267). Sosyal medya ile birlikte ünlüler ve hayranlar, kitle medyasına bağlı kalmadan ve doğrudan etkileşime geçebilmektedirler (Bennett, 2014, pp. 149-150; Duvall \& Heckemeyer, 2018, p. 395). Ünlüler, izleyiciyle bağ kurarak aktivist hareketleri destekleyebilmektedirler (Bennett, 2013). Buente \& Rhatnayake (2016, p.7), ünlü aktivizmi kapsamında volkanik bir dağ olan ve Hawaii Adaları'nda yer alan Mauna Kea'ya kurulması planlanan teleskopa karşı Twitter'da oluşturulan \#WeAreMaunaKea hashtagine ünlülerin katılımlarını incelemişlerdir. Gerçekleştirdikleri araştırma sonucunda, ünlü olmanın yaratılacak aktivist etkiyi garantilemediği belirlenmiştir. Buna göre Twitter üzerindeki dijital aktivizmde ünlülerin etkisi, ünlüler ve diğer kullanıcılar arasındaki etkileşime bağı olmaktadır. Twitter'daki hashtaglerin incelendiği bir diğer araştırmada ise siyahi ünlülerin \#BlackLivesMatters ve \#BLM hashtaglerine verdikleri destek ele alınmıştır. Buna göre harekete katılan ünlüler, politik görüşlerini paylaşırken hayranları ile Twitter üzerinden bir yakınlık kurmakta ve aktivist liderler olarak öne çıkmaktadırlar (Duvall \& Heckemeyer, 2018, p. 394).

Gerçekleştirilen bir başka araştırmaya göre; sosyal ağlarda daha yüksek merkeziyete sahip olan ünlüler, aktivist ve hayırsever davranışlara eğilimli olmaktadırlar. Ünlülerin aktivizim çerçevesinde göz önünde bulunmaları, daha çok kişinin benzer davranışlar sergilemesine katkıda bulunmaktadır (Yang et al., 2018, p. 12). Ünlüler, dağınık haldeki kitlelere ulaşabilme ve onları harekete geçirebilme gücüne sahiptirler (Hart \& Tindall, 2009). Bennet (2014) sosyal medyada ünlü aktivizmini Lady Gaga örneği üzerinden ele alarak Lady Gaga'nın sosyal medya platformları üzerinden hayranlarıyla kurduğu yakınlık sayesinde onları toplumsal konulara karşı ilgili hale getirdiğini ve hayranları tarafından aktivist bir ünlü olarak görüldüğünü belirtmektedir. Hunting ve Hinck (2017) ünlülerin, hayranlarılla yakınlık kurarak onların toplumsal sorunlara duyarlı olmalarını sağlayabileceklerini belirtmektedirler. Literatürde ünlü aktivizminin toplumsal sorundan çok ünlüye dikkat çekmesi nedeniyle eleştirildiğini, ancak aktivist ünlü ve gündeme getirdiği toplumsal sorunun her zaman birbirinden bağımsız olması gerekmediğini öne süren araştırmacılar, bu doğrultuda örnek olay incelemesi kapsamında lan Somerhalder'ı ve 
çevre sorunlarına yönelik çalışmalarını ele almaktadırlar. Araştırma sonucunda; Somerhalder'ın, sosyal medya paylaşımlarında sahip olduğu ünlü kimliği, ekranda canlandırdığı karakter, ilgilendiği toplumsal sorunlar ve hayranları arasında bir etkileşim kurduğu ortaya konmaktadır. Bu bağlamda oyuncunun hayranlarıyla sosyal medya aracılığıyla kurduğu yakınlık, ünlü aktivizmini etkili hale getirmektedir.

Marwick \& Boyd (2011) ise ünlüyü bir pratik olarak ele almaktadır. Bu bağlamda ünlüler; toplumun geneli ve hayranlar tarafından tanınan kişiler olmalarının yanı sıra ünlü olmayan kişiler, bir diğer deyişle mikro-ünlüler de bu kavram içerisinde ele alınabilmektedir. Sosyal medyayla birlikte geleneksel anlamda ünlü olmak da değişim göstermektedir. Senft (2008, p. 25) mikro-ünlüleri; video, blog, sosyal ağlar üzerinden internet yoluyla popülerliğini arttıran kişiler olarak ifade etmektedir. Mikro-ünlüler, sosyal medya platformlarındaki takipçilerini birer hayran kitlesi olarak görerek popülerliklerini arttırma amacıyla hareket etmektedirler. Geleneksel anlamdaki ünlüler de mikro-ünlülerle benzer taktiklerden yararlanmaktadırlar (Marwick \& Boyd, 2011 , p. 141). Tüfekçi (2013, p. 857) mikro-ünlü aktivistleri, politik bir güdü ile harekete geçerek sosyal medya üzerinden bir soruna dikkat çeken kişiler olarak tanımlamaktadır. Bu kişiler, çoğunlukla vatandaş gazeteciler olarak görev almaktadırlar. Lawson (2018) ise sosyal medyada ünlü aktivizmini, feminizm ve kadın hakları çerçevesinde ele almaktadır. Ünlülerin bulut depolama hesaplarının hacklenerek fotoğraflarının yayınlanmasına yönelik tepkiler, Hollywood'da gerçekleşen protestolar gibi ünlülerin içinde yer aldığı çeşitli aktivist etkinlikler, hashtagler yoluyla sosyal medyaya yansımaktadır.

Literatürde ünlü aktivizminin genel olarak uluslararası siyaset (Budabin, 2015); uluslararası ilişkiler (Huliaras \& Tzifakis, 2010); Birleşmiş Milletler (Cooper, 2008; Wheeler, 2011); hayırseverlik (Jeffreys \& Allatson, 2015; Hassid \& Jeffreys, 2015; Jeffreys \& Xu, 2017; Yang et al., 2018) çerçevesinde ele alındığı görülmektedir. Ayrıca literatürde, sosyal medyada ünlü aktivizmini ele alan çalışmalar (Marwick \& Boyd, 2011; Tüfekçi, 2013; Bennett, 2014; Buente \& Rhatnayake, 2016; Duvall \& Heckemeyer, 2018; Ellcessor, 2018) da bulunmaktadır.

\section{AMAÇ VE YÖNTEM}

Dijital aktivizme ve ünlü aktivizmine ilişkin literatür değerlendirildiğinde ünlülerin; toplumda göz önünde oldukları, toplumsal sorunlara ve amaçlara yönelik farkındalık 
yaratma, harekete geçirme gibi özellikler taşıyabildikleri anlaşılmaktadır. Bu özellikleri değerlendiren ünlüler ise birer aktivist ünlü kimliğine sahip olmaktadır. Ünlüler günümüzde aktivist faaliyetleri, tıpkı bireylerin gerçekleştirdikleri gibi sosyal medya üzerinden gerçekleştirebilmektedirler. Bu bağlamda sosyal medyada da aktivist bir ünlü kimliği oluşturabilmekte veya var olan aktivist kimliklerini sosyal medya üzerinden yansıtabilmektedirler. Bu çalışmanın ana amacı, ünlülerin aktivist kimliklerini sosyal medya üzerinde nasıl yansıttıklarını değerlendirmektir. Bu amaç doğrultusunda aktivist bir ünlü kimliği ile dikkat çeken Haluk Levent'in Twitter paylaşımları amaçsal örneklemle ele alınarak incelenmiştir. Bu bağlamda Haluk Levent'in aktivist kimliğini Twitter paylaşımlarına yansıtıp yansıtmadığı, nasıl yansıttığı ele alınmaktadır.

Araştırma kapsamında "Haluk Levent, Twitter hesabında aktivist ünlü kimliğini ortaya koymakta mıdır?" ve "Haluk Levent, Twitter hesabunda aktivist ünlü kimliğini nasıl ortaya koymaktadır?" sorularına yanıt aranmaktadır. Bu bağlamda aşağıdaki unsurlar irdelenecektir:

- Belirlenen tarih aralığında Haluk Levent'in Twitter'da gönderilerinde aktivist içeriklerin olup olmadığı,

- Belirlenen tarih aralığında Haluk Levent'in Twitter gönderilerinin metin tonu,

- Belirlenen tarih aralığında takipçilerin etkileşim durumu,

- Belirlenen tarih aralığındaki gönderilerde ünlü-sivil toplum etkileşim modelinin yansıtılıp yansıtılmadığı ve yansıtılıyorsa hangi modelin yansıtıldığı,

Araştırma kapsamında, betimsel araştırma yöntemlerinden içerik analizi tekniği kullanılmıştır. İçerik analizi, çeşitli metinsel ve metinsel olmayan analizlerin yer aldığı yöntembilimsel bir alan ve mevcut malzemeye dayalı ampirik bir çalışma olarak belirtilmektedir. Twitter verilerinin incelenmesinde sıklıkla içerik analizinden yararlanılmaktadır (Einspanner, Dang-Anh, \& Thimm, 2016, p. 139). Bu bağlamda araştırma kapsamında Haluk Levent'in Twitter üzerinde gerçekleştirdiği paylaşımlar irdelenmiştir. Amaçsal örneklem olarak Haluk Levent'in Twitter hesabının seçilmesinin en temel nedenini Haluk Levent'in yardımseverlik imajı üzerinden giderek artan popülaritesi olmaktadır. Haluk Levent'in gerçekleştirdiği yardım çalışmaları ve kurmuş olduğu Ahbap Derneği'nin çalışmaları sosyal medyanın yanı sıra geleneksel medyada da sık sık yer almaktadır. Ayrıca Social Blade internet sitesi üzerinden elde edilen istatistiklere göre Haluk Levent'in Twitter takipçilerinin sayısı 
da düzenli bir biçimde artış göstermektedir ("User Statistics Table for Haluk_ Levent", 2018). Bu durum Haluk Levent'in Twitter üzerinden kitlelere erişim gücünün de düzenli bir biçimde artış gösterdiği ve Twitter kullanıcılarının da Haluk Levent'in paylaşımlarından haberdar olmak istedikleri şeklinde yorumlanabilmektedir. Ayrıca Haluk Levent, kendi kurmuş olduğu Ahbap Derneği ve Ahbap Platformu'nu Twitter üzerinden öne çıkaran paylaşımlarda da bulunmaktadır. Bu bağlamda Haluk Levent'in aktivist ünlü kimliğinin irdelenmesinde bir destekleyici olması bakımından amaçsal örneklem ile Ahbap Platformu da çalışmanın önemli bir parçasını oluşturmaktadır. Ahbap Derneği; dayanışma, paylaşım ve aidiyet üzerine kurulu bir işbirliği hareketi olarak tanımlanmaktadır ("Derneğin Amacı", 2018). Twitter üzerinden gerçekleştirilen yardım etkinliklerinin resmileştirilmesi ile Haluk Levent tarafından kurulan derneğin organizasyonu ise Ahbap Platformu olarak adlandırılmaktadır. Derneğin, çeşitli şehirler ve üniversiteler bazında gönüllü ağları bulunmaktadır. Derneğin gönüllüleri, büyük oranda gençlerden oluşmaktadır. Gönüllüler, internet sitesi üzerinden derneğe üye olarak bir oryantasyon sürecinden geçmektedirler. Gönüllüler, özellikle sosyal medyada yer alan paylaşımlar üzerinden ihtiyaç sahiplerine ulaşmaktadırlar. Gerçekleştirilen yardımlara ve etkinliklere dair paylaşımlar da Twitter başta olmak üzere çeşitli sosyal medya platformları üzerinden gerçekleştirilmektedir. Bu bağlamda Ahbap Derneği'nin; Haluk Levent'in birbirlerinden bağımsız olarak gerçekleştirdiği yardımların tek bir çatı altında toplanması, belirli bir düzenin sağlanması ve gönüllülerin biraraya gelerek bir ağ oluşturmaları amacıyla kurulduğu anlaşılmaktadır. Ayrıca derneğin kurulmasında ve sürdürülmesinde Twitter'ın da bir etki sahibi olduğu anlaşılmaktadır. 15 Ekim 2018 - 15 Aralık 2018 tarihleri arasında Haluk Levent'in resmi Twitter hesabı, aktivist kişiliğinin Twitter gönderilerine yansımasının irdelenmesi amacıyla incelenmiştir. Inceleme için 15 Ekim 2018 - 15 Aralık 2018 tarihlerinin seçiminde yeni okul yılının başlaması ile eğitime ilişkin konuların gündemde olması ve kırtasiye ihtiyaçları gibi okula özgü ihtiyaçların gündemde olması, ülke gündemine bağlı olarak şiddet, istismar gibi konuların gündemde olması, havaların soğumasına bağlı olarak ısınma, barınma, kışıı giyim ihtiyaçlarının artması ve Twitter hesabı üzerinden paylaşılan iletilerin güncel bir zaman dilimine ait olmasıdır. Bu kapsamda 513 gönderi kategorilere göre araştırılmış ve veriler SPSS 22.0 programına girilerek analiz edilmiştir. Araştırmada kapsamındaki kodlama cetveli ve kategoriler, literatür ve model çerçevesinde oluşturulmuştur. Veri toplama sürecinde iki kodlayıcı çalışmıştır. Kodlayııılar arasındaki güvenilirliği arttırmak amacıyla kodlama aşaması 
başlamadan önce görüş birliği sağlamak üzere kodlayıcılar arasında toplantı yapılmış ve kategoriler detaylı bir şekilde açıklanmıştır. Bu toplantıdan sonra pilot çalışma için her kodlayıcının aynı tarihleri kapsayan toplam 3 gündeki tüm sosyal medya içeriklerini kodlamaları istenmiştir. Her iki kodlayıcının veri girişleri karşılaştırılarak farklı verilerin nedenleri tekrar tartışılmış ve görüş birliğine varılmıştır. Bu kapsamda çalışmanın kodlamasında gereken değişiklikler yapılarak her iki kodlayıcı uzlaşmıştır. Kodlayıcılar belirlenen tarih aralıklarına göre kodlama yaparak verileri SPSS programına girmiştir. Kodlayıcılar arasındaki güvenilirliği test etmek için Krippendorf Alfa katsayısı hesaplanmıştır. KALPHA değeri $a=0,741$ olarak saptanmıştır. Bu değer kabul edilebilir değer aralığı içindedir.

\section{BULGULAR}

Ünlülerin aktivist kimliklerini sosyal medya üzerinde nasıl yansıttıklarını değerlendirmeyi amaçlayan bu çalışmada içerik analizi tekniğinden yararlanılarak amaçsal örneklem ile Haluk Levent'in Twitter paylaşımları incelenmiştir. Bu doğrultuda elde edilen bulgular aşağıda yer almaktadır. Araştırmada ilk olarak Haluk Levent'in Twitter hesabının genel özellikleri incelenmiştir. Bu doğrultuda Haluk Levent'in Twitter hesabındaki toplam gönderi sayısı, takipçi ve takip edilen sayısı, gönderilerin etkileşim durumunun incelenmesi açısından Tablo 1'de yer alan tweetlere gelen beğeni-yorumretweet sayıları, tweetlerde görsel bulunma durumu ve Haluk Levent'in gerçekleştirdiği retweetlere yer verilmektedir. Sonrasında Haluk Levent'in Haluk Levent'in Twitter hesabında gerçekleştirdiği gönderilerin konulara göre dağılımı ve beğeni durumu incelenerek Tablo 2'de yer verilmektedir. Tablo 3'te gönderilerin metin tonu ve aktivist içerik durumu yer alırken son olarak ise ünlü-sivil toplum etkileşim modeli kategorileri çerçevesinde Haluk Levent'in Twitter hesabındaki gönderileri incelenmektedir.

\section{Haluk Levent'in Resmi Twitter Hesabının Temel Özellikleri}

Aralık 2018 tarihi itibariyle Haluk Levent'in Twitter hesabı incelenmiştir. Hesabın açıldığı günden ilgili tarihe kadar 15,8 bin tweet atılmıştır. Haluk Levent'in resmi hesabından 698 kişi takip ediliyorken 1,27 milyon kişi tarafından takip edilmektedir. Araştırma kapsamında 15 Ekim 2018-15 Aralık 2018 tarihleri arasında toplam 513 gönderi incelenmiştir. Gönderi dağılımına bakıldığında incelenen gönderilerin, $\% 91,9$ 'i yani 471'i Haluk Levent'in kendi gönderileri olup \%8,1'inin yani 42'sinin retweetlerden oluştuğu görülmektedir. 


\section{Haluk Levent'in Gönderilerinin Etkileşim Durumu}

Tablo 1'de yer alan Haluk Levent'in resmi Twitter hesabındaki gönderilerinin beğeni oranı incelendiğinde en yüksek oranda \%47,6 ile 1-1000 beğeni kategorisinde beğeni bulunmaktadır. İkinci sırada ise \%23,6 oranında ise 1001-2000 arasında beğeni bulunmaktadır. Sonrasında ise $\% 11,1$ ile 6001-üstü, $\% 8$ ile 2001-3000, \%5,3 ile 30014000, \%2,7 ile 4001-5000, \%1,8 ile 5001-6000 beğeni kategorisi gelmektedir. Yorum oranları incelendiğinde ise en yüksek oranda \%73 ile 1-50 arasında yorum yazıldığı görülmektedir. Sonrasında ise $\% 9,7$ ile 51-100, \%5,5 ile 101-150, \%4,3 ile 350-üstü, $\% 3,5$ ile $151-200, \% 2,1$ ile 201-250, \%1 ile 301-350, \%0,8 ile 251-300 yorum kategorileri gelmektedir. Retweet oranlarına bakıldığında Haluk Levent'in paylaştığı gönderilerin en yüksek oranda $\% 65,1$ ile 1-100 arasında retweet edilmektedir. Sonrasında ise $\% 24,4$ oranında 101-500, \%5,8 oranında 501-1000, \%1,8 oranında 3001-üstü, \%1,4 oranında $1001-1500, \% 0,8$ oranında $2500-3000, \% 0,4$ oranında $1501-2000, \% 0,4$ oranında 20012500, retweet yapıldığı saptanmıştır. Gönderilere gelen yorumlar, beğeni ve retweet oranlarının ortalama bir seviyede olduğu belirtilebilmektedir.

\section{Haluk Levent'in Twitter Gönderilerinde Görsel Bulunma Durumu}

Haluk Levent'in Twitter hesabındaki gönderilerde görsel bulunma durumuna bakıldığında araştırma kapsamında incelenen toplam 513 gönderi arasındaki 428 $(\% 83,4)$ gönderide görsel bulunmaktadır. $85(\% 16,6)$ gönderide ise görsel bulunmamaktadır. Özellikle sosyal medyada, metin içeriğinin yanı sıra takipçilerin dikkatini çekebilmek için görsellik önem taşımaktadır. Haluk Levent'in de paylaşımlarının önemli bir çoğunluğunda metnin yanı sıra görsellerden yararlanarak hem takibi arttırmayı hem de dikkat süresini uzatmayı hedeflediği belirtilebilmektedir.

\section{Haluk Levent'in Twitter Gönderilerinde Haydi Ahbap ve Ahbap Platformu Hesaplarından Retweet Yapma Durumu}

Haluk Levent'in Twitter gönderilerinin retweet olup olmadığı ve bu retweetlerin Haydi Ahbap ve Ahbap Platformu'nun hesaplarına göre dağılımları incelenmiştir. Buna göre araştırma kapsamında incelenen 513 gönderinin 42'si $(\% 8,1)$ Haluk Levent tarafından retweetlenen gönderilerken 417 'i $(\% 91,9)$ kendi tweetlerinden oluşan gönderilerdir. Retweetler arasından 31'i (\%6) Haydi Ahbap ve Ahbap Platformu hesaplarından $11^{\prime} \mathrm{i}(\% 2,1)$ diğer hesaplardan retweetlerdir. Sadece retweetler 
incelendiğinde ise $31(\% 73,2)$ tweetin Haydi Ahbap, Ahbap Platformu'nun içerikleri olduğu görülmektedir. Haluk Levent, Twitter hesabında yaptığı retweetlerde özellikle Ahbap Platformu'nun ulaştığı kişilere teşekkür etmek veya yardım etmeyi amaçladığı kişilerin sesini geniş kitlelere duyurmak üzere gönderileri paylaşmaktadır.

\section{Haluk Levent'in Twitter Gönderilerinde, Mention Özelliği ile Haydi Ahbap ve Ahbap Platformu Hesaplarına Etiketlemesi}

Haluk Levent'in resmi Twitter hesabından mention özelliğinden yararlanarak Ahbap Platformu'nun Twitter hesabını etiketlediği tweetlerin dağılımına bakıldığında ise toplam 513 gönderinin 107'sinde (\%20,9) Ahbap Platformu'nun Twitter hesabından söz edilmektedir. Bu gönderilerle özellikle kurucusu olduğu derneği öne çıkardığı görülmektedir. Böylelikle hem derneğin ve gönüllülerin çalışmalarını daha geniş kitlelere duyurarak toplumsal bilinci arttırmaya çalışmakta hem de kendi kişisel markasını Ahbap Platformu ile bağdaştırarak hayranlarının da farkındalık seviyelerinin arttırılmasını hedeflediği öngörülmektedir.

\section{Haluk Levent'in Twitter Hesabındaki Gönderi Konuları ve Beğeni Durumu}

Araştırma kapsamında Haluk Levent'in Twitter hesabındaki gönderilerin konulara göre dağılımı incelenmektedir. Buna göre gönderilerde, \%30 oranında sağlık ile ilgili konuların öncelikli olduğu saptanmıştır. "Sağlık" konusunda özellikle maddi yetersizlikler nedeniyle ameliyat olunamaması ya da donör ihtiyacı gibi olunan konulara değinmektedir. Kendisi de hareketi uzun süre gündemde tutmak ve geniş kitlelere seslenebilmek adına kendine ait bir eşyayı hediye olarak vermek gibi çalışmalar gerçekleştirmektedir. Bu bağlamda ünlü olmasının avantajlarını, yardım kampanyalarına da yansıtmaktadır. Gönderi konuları arasında ikinci sırada, "Bağış ve Burs" konusu \%21,6 oranıyla yer almaktadır. "Bağış ve Burs" konusunda eğitim, okullardaki eksiklerin tamamlanması, tekerlekli sandalye alımı gibi çalışmaların yer aldığı görülmektedir. Bu bağlamda Haluk Levent Twitter hesabında bağış ve yardım hareketini başlatmaya veya Ahbap Platformu'na yönlendirerek farklı şehirlere ulaşmaya yönelik gönderilerde bulunmaktadır. Gönderi konularının dağılımında üçüncü sırada \%11,3 oranında "Sanatçı Kimliği" yer almaktadır. Sanatçı kimliğinin yansıması olarak verdiği konserleri ve şarkılarını da hesabından paylaşmaktadır. Bu veriler doğrultusunda en yüksek oranda gönderi yapılan konuların Sağlık (154 gönderi, \%30), Bağış ve Burs (111 gönderi, \%21,6), Sanatçı 
Kimliği (58 gönderi, \%11,3) olduğu görülmektedir. İlgili konuları sırasıyla 44 gönderi ile $(\% 8,6)$ Yoksulluk, 15 gönderi ile $(\% 2,9)$ Çocuk İstismarı, 12 gönderi ile $(\% 2,3)$ Çevre, 9 gönderi ile $(\% 1,8)$ Eğitim, 9 gönderi ile $(\% 1,8)$ Hayvan Hakları, 4 gönderi ile $(\% 0,8)$ Sanata Duyarlılık, 2 gönderi ile $(\% 0,4)$ Şiddet ve 2 gönderi ile $(\% 0,4)$ Madde Bağımlılığı konuları izlemektedir.

Tablo 2'de gönderi konularına göre beğeni dağılımlarına yer verilmektedir. Buna göre en yüksek beğeni; 6001 ve üstü sayıda beğeni kategorisinde 26 gönderi ile $(\% 44,8)$ "Sanatçı Kimliği" konusunda yer almaktadır. İkinci sırada "Çocuk İstismarı" (\%20) ve üçüncü sırada "Çevre" $(\% 16,7)$ konuları yer almaktadır. Bu gönderilerin sayısının fazla olmamasına karşın özellikle sanatçı yönünü yansıttığı içeriklerin beğeni sayısı anlamlı bir oranda diğer içeriklere göre yüksektir. Bunun nedeninin hayran kitlesinin verdiği tepkiler olduğu öngörülmektedir. Tüm gönderilerin beğeni oranları değerlendirildiğinde ise ilk sırada \%30 ile Sağlık konusu yer almaktadır. illgili konuyu sırasıyla \%21,6 ile Burs ve Bağış, \%18,1 ile Diğer, \%11,3 ile Sanatçı Kimliği, \%8,6 ile Yoksulluk, \%2,9 ile Çocuk İstismarı, \%1,8 ile Hayvan Hakları, \%1,8 ile Eğitim, \%0,8 ile Sanata Duyarlılık, \%0,4 ile Madde Bağımlılığı, \%0,4 ile Şiddet konuları izlemektedir.

\section{Haluk Levent'in Twitter Gönderilerinde Metin Tonu ve Aktivist İçeriğe Göre Dağılımı}

Tablo 3'te Haluk Levent'in Twitter hesabındaki gönderilerin metin tonunun incelemesi yer almaktadır. Buna göre en yüksek oranda \%93,2 ile 478 gönderide samimi, \%5,5 ile 28 gönderide mizahi ve \%1,2 ile 7 gönderide ciddi bir ton kullanılmaktadır. Bu durumun, sanatçının topluma yansıtmak istediği karakter ile paralellik gösterdiği düşünülmektedir. Ayrıca, takipçilerle kurulan samimi etkileşim ile toplumu yardım çalışmalarına katılmaya teşvik edeceği düşünülmektedir. Bu durum da ünlü ve takipçileri arasında kurulması gereken yakınlığın desteklenmesini sağlamaktadır. Tablo 8'de ayrıca Twitter gönderilerinde kullanılan metin tonu ile gönderilerin aktivist içerik olması durumu incelenmiştir. Araştırmada incelenen 513 gönderinin 391'i $(\% 76,2)$ aktivist içerik iken 122'si $(\% 23,8)$ aktivist içerik olmayıp özel yaşam, sanat yaşamı gibi konuları kapsamaktadır. Aktivist içerikli gönderilerde ağırıklı olarak (\%74,9, 384 gönderi) samimi bir ton kullanıldığı saptanmıştır. Aktivist içerikli gönderilerde \%1,4 ile 7 gönderide ciddi bir ton kullanılırken mizahi tonun hiç kullanılmamış olması dikkat çekmektedir. Özellikle aktivist içeriklerde birlik, 
beraberlik, yardımlaşma duygusunu iletebilmek amacıyla daha samimi ve daha ciddi durumlarda, durumun ciddiyetini belirtmek adına ciddi tonda içerikler paylaşıldığı belirtilebilmektedir.

\section{Haluk Levent'in Twitter Gönderilerinde Ünlü ve Sivil Toplum Etkileşimi Modeli Kategorileri}

Araştırma kapsamında son olarak ünlüler ve sivil toplum etkileşimi modelinden yararlanılarak Haluk Levent'in Twitter hesabındaki gönderilerine göre hangi kategoride yer aldığı belirlenmeye çalışılmıştır. Buna göre toplam 513 gönderinin 110 'unda $(\% 21,4)$ herhangi bir kategori saptanamamıştır. $379(\% 73,9)$ gönderide Sözcü, 20 (\%3,9) gönderide Koruyucu, 3 (\%0,6) gönderide Elçi/Yazar, 1 (\%0,2) gönderide ise Vizyoner Lider olarak yer aldığı belirlenmiştir. Bu bağlamda Haluk Levent'in resmi Twitter hesabındaki tweetler çerçevesinde ünlüler ve sivil toplum etkileşimi modeline göre Sözcü kategorisinde sosyal medya üzerindeki aktivizminin değerlendirilmesi mümkündür.

Araştırma kapsamında "Haluk Levent, Twitter hesabında aktivist ünlü kimliğini ortaya koymakta mıdır?" ve "Haluk Levent, Twitter hesabunda aktivist ünlü kimliğini nasıl ortaya koymaktadır?" sorularına yanıt aranmış olup bu doğrultuda Haluk Levent'in Twitter hesabı genel özellikleri ile incelendikten sonra belirlenen tarih aralığında olmak üzere Haluk Levent'in Twitter gönderilerinde aktivist içeriklerin olup olmadığl; gönderilerin hangi konular üzerine olduğu; Twitter gönderilerinin metin tonu; takipçilerin etkileşim durumu; gönderilerde ünlü-sivil toplum etkileşim modelinin yansıtılıp yansıtılmadığı; yansıtılıyorsa hangi modelin yansıtıldığı unsurları irdelenmiştir. Elde edilen bulgular, Tartışma ve Sonuç bölümünde değerlendirilecektir.

\section{TARTIŞMA VE SONUÇ}

Değişen teknolojik altyapı ile geleneksel pek çok araç ve unsur dijitalde de kendine bir yer bulmaktadır. Aktivizm de geleneksel yapıdaki formunu dijitale taşıyarak sadece sıradan insanlar için değil, ünlüler için de tercih edilen bir aktivist teknoloji haline gelmiştir. Dünyada ve Türkiye'de pek çok ünlü, sosyal medya hesapları üzerinde toplumun dikkatini çekmeye ve yardım eli uzatılmasına aracı olmaktadır. Ünlüler, kendileri aktivist eylemlerin parçası olurken aynı zamanda toplumun da bu etkinliklerin bir parçası olmaları için sosyal medya üzerinden yaptıkları paylaşımlarla 
onları yönlendirmektedir. Türkiye'de bu konuda ele alınabilecek isimlerden biri Haluk Levent olmaktadır. Haluk Levent'in aktivist bir sanatçı kimliği yansıttığı bilinmektedir. Intiyacı olan bireylere yardım etmeye çalışması sonucunda Ahbap Derneği ve Ahbap Platformu'nu kurarak bu kimliği resmi bir boyuta taşımaktadır. Bir işbirliği platformu olarak tanımlanan dernekte, gönüllülük esasına göre yapılan çalışmalar da yine Haluk Levent'in Twitter hesabından paylaşılarak diğer kişilerin de harekete geçmesi amaçlanmaktadır. Bu çalışma kapsamında Haluk Levent'in, dijital aktivist yönünün irdelenmesinin yanı sıra Ahbap Platformu'nun da yansıtııp yansıtılmadığı irdelenmiştir.

Araştırmada incelenen tweetlere göre Haluk Levent'in paylaşımlarında sadece $\% 23,8$ oranında aktivizm dışı içerikler yer alırken (sanatçı yönü, özel yaşamı, genel bir bilgi), \%76,2 oranında aktivist etkinliklere davet veya harekete geçirme amacıyla paylaşımlar yer almaktadır. Bu çerçevede bir diğer önemli veri \%11,3 oranında sanatçı yönünü temsil eden içerikler paylaşması iken $\% 88,7$ oranında ise yardım, bağış vb konulara yönelik paylaşımlarda (retweetler de dâhil olmak üzere) bulunmasıdır. Bu bağlamda Haluk Levent'in ünlü olarak yarattığı marka kişiliğini, bir diğer deyişle ünlü kimliğini aktivist çabalarının takipçileriyle paylaşımına da yansıtarak takipçilerini yardım, sağlık, bağış, çevre, çocuk istismarı vb konularda da bilgilendirmeyi ve harekete geçirmeyi amaçladığı söylenebilmektedir. Aktivist içerikler içinde en önemli payı sağlık almaktadır. Sağlık başlığı altında ameliyat, donör bulunması gibi bireysel olarak çözüm bulmanın zor olduğu ve geniş kitlelerin desteğiyle çözüm bulunabilecek konuların olduğu gözlemlenmiştir. Aynı zamanda "Sağlık" konusu kapsamında paylaşılan durumların takip edildiği ve elde edilen sonuçların da takipçilerle paylaşıldığı saptanmıştır. Literatürde görüldüğü üzere ünlü ve takipçiler arasında etkileşim yaratılması ve çabaların sonucunun takipçilerle paylaşılması, takipçilerin yardım ihtiyacı olan kişilerle empati kurmasına ve aktivist ünlüler ile takipçiler arasında yakınlık hissi kurulmasına katkı sağlamaktadır. Ayrıca bazı durumlarda Haluk Levent, takipçilerin ilgisini ve desteğini alabilmek için birtakım hediyeler verme, evlerine misafir olma gibi sürprizler de vadederek takipçileriyle sanatçı kimliği üzerinden yakınlık kurmayı amaçlamaktadır. Gönderi konuları arasında ikinci sırada "Bağış ve Burs" başlığı yer almaktadır. Bu konu başığı altında özellikle maddi durumu yeterli olmayan kişilerin eğitim giderlerini ve eksiklerini karşılamak amacıyla başlatılan bağış ve burs kampanyaları, tekerlekli sandalye veya erzak sağlanması gibi çalışmaların yer aldığı görülmektedir. Bu bağlamda Haluk Levent, Twitter hesabında bağış ve yardım hareketini başlatmaya 
veya Ahbap Platformu'na yönlendirerek farklı şehirlere ulaşmaya yönelik gönderilerde bulunmaktadır. Bu çalışmaların sonuçlarını da gerek teşekkür metinleri gerek görseller aracılığıyla yine Twitter hesabından paylaşmaktadır. Gönderi konularının dağııımında üçüncü sırada "Sanatçı Kimliği" yer almaktadır. Bir şarkıcı olan Haluk Levent bu bağlamda Twitter hesabında konserlerini, konser için gittiği mekanları da paylaşmaktadır. Bu bağlamda Twitter hesabında takipçileriyle sanatçı kimliği üzerinden de bir ünlü olarak bağ kurduğu anlaşılmaktadır. İlk üç sıradaki konuyu sırasıyla Yoksulluk, Çocuk İstismarı, Çevre, Eğitim, Hayvan Hakları, Sanata Duyarlılık, Şiddet ve Madde Bağımlılığı konuları izlemektedir. Twitter hesabında yaptığı gönderilerde genel olarak Ahbap Platformu öne çıkarılıyor olsa da T.C. Orman ve Tarım Bakanlığı tarafından başlatılan ve Haluk Levent'in de destek verdiği ağaçlandırma kampanyasını da Twitter hesabından detaylarıyla paylaştığı saptanmıştır. Gündeme bağlı olarak gerçekleştirdiği Twitter paylaşımlarında da çevre, kadına şiddet, çocuk istismarı, hayvan hakları, madde bağımlılığı gibi farklı konulara yer vererek toplumsal duyarlıı̆̆ı arttırmaya veya yardım kampanyası başlatmaya yönelik paylaşımlarda bulunduğu görülmektedir.

Araştırma kapsamında irdelenen bir diğer unsur ise gönderilerde yer alan metinlerin tonudur. Haluk Levent'in paylaştığı içeriklerde samimi bir ton olduğu saptanmıştır. Ortaya koyduğu kişisel markasında da samimi bir kişilik ortaya koymaktadır. Bu bağlamda marka kişiliği ile de metin tonları paralellik göstermektedir. Bir diğer yandan kurduğu Ahbap Derneği'nde gönüllü çalışacak kişilere seslenmesinde kullandığı tonun yakın, sıcak ve samimi olması önemlidir. Sadece mizah veya sadece ciddiyetle bağ kurmak bu tür etkinlikler için sürdürülebilir değildir. Hiçbir aktivist içerikte mizah tonunu kullanmamış olması dikkat çekicidir. Bununla birlikte özel yaşamı ya da sanat yaşamı ile ilgili konularda mizahı kullanması aktivist etkinliklere farklı yaklaştığını göstermektedir. Toplumsal olarak yardımlaşma, el ele verme, sağlık gibi konularda şaka yapılmaması gerekliliği kültürel bir unsur olup bu durumu sosyal medya hesabına yansıttığı anlaşılmaktadır. Bu bağlamda literatürde ünlü aktivizminin dijitalleşmesi sürecinden (Andersson, 2007, p. 10) bahsedilse de gelenek ve kültür konularında var olan geleneksel tonun, dijitalde de varlığını sürdürdüğü yargısına ulaşılabilmektedir.

Araştırma kapsamında irdelenen bir diğer konu olan takipçi etkileşim durumu verilerine göre yorum, beğeni ve retweet seviyesinin aktivizm konularında ortalama seviyede olduğu ancak sanatçı yönünü ortaya çıkartan paylaşımlarda daha yüksek 
beğeni, yorum ve retweet seviyesine sahip olduğu görülmektedir. Haluk Levent ve takipçi kitlesi arasında etkileşim bulunsa da bu etkileşim, ağırlıklı olarak kendisinin sanatçı yönüne gelmektedir. Veriler incelendiğinde aktivist gönderiler bakımından sağlık, burs ve bağış konularındaki takipçi beğenilerinin oranının en fazla olmasına karşın tüm gönderiler göz önüne alındığında en yüksek beğeninin sanatçı yönünü yansıttığı paylaşımlarda olduğu saptanmıştır. Bu veriler ışığında Haluk Levent'in Twitter takipçilerinin kendisinin aktivist çabalarını sosyal medya hesabına yansıtması ile yani aktivist kimliği ile ilgilendikleri, ancak sanatçı kimliğiyle daha yüksek düzeyde ilgilendikleri sonucuna ulaşılabilmektedir. Ayrıca Haluk Levent'in literatürde yer alan bilgilerle tutarlı bir biçimde medya yansıması ve hayran tabanı çerçevesinde ünlü kimliğinden yararlanarak hem sosyal medya hem de geleneksel medya üzerinden farkındalık oluşturmaya çalıştığı anlaşılmaktadır. Literatürde yer aldığı üzere kişinin sahip olduğu ün, medya yansımasını arttırarak farkındalık yaratma ve dikkat çekme için yararlı olmaktadır (Yang, Zhou \& Zhang, 2018).

Budabin (2015, p. 401) ise ünlülerin sahip oldukları takipçiler ve hayranlar sayesinde kendi aktivist çalışmalarını hayata geçirebildiklerini ifade etmektedir. Haluk Levent'in aktivist çalışmaları ve kurmuş olduğu dernek de bu duruma bir örnek oluşturmaktadır. Ünlüler hayranları ile yakınlık kurarak onları toplumsal sorunlara daha duyarlı hale getirebilmektedirler. Ünlülerin, hayranları ile sosyal medya üzerinden kurdukları etkileşim aynı zamanda onların toplumsal sorunlarla da etkileşim kurmalarına yardımcı olabilmektedir (Bennet, 2014; Hunting \& Hinck, 2017). Haluk Levent'in Twitter gönderileri ile beğeni, yorum, retweet yolu ile etkileşime geçen takipçileri birer kliktivist olarak görev almaktadırlar. Ayrıca başta hayranları olmak üzere Ahbap Platformu'nda pek çok gönüllü görev almaktadır. Gönüllülerin, Ahbap Platformu ile tanışmalarının büyük ölçüde Haluk Levent'in aktivist ünlü kimliğine dayandığı öne sürülebilmektedir. Bu durum birer rol modeli olan ünlülerin, hayranları ve toplum üzerinde etki sahibi olduklarını (Hanna et al., 2018) ve Hart ve Tindall'ın (2009) da belirttiği üzere ünlünün harekete geçirme gücünü ortaya koymaktadır.

Ünlülerin aktivizmi farklı yönleriyle olabilmektedir. Bazı ünlüler yardım faaliyetlerine destek olurken bazı ünlüler topluma belli bir konuda liderlik ederek onları yönlendirmektedir. Haluk Levent'in Twitter hesabındaki paylaşımları Huddart'ın (2005) ünlü ve sivil toplum etkileşimi modeline göre irdelenmiştir. Toplumla ünlüler arasındaki etkileşimin ele alındığı modele göre Haluk Levent, sözcü kategorisinde 
değerlendirilmektedir. Kendi çabasıyla kurduğu Ahbap Derneği için duyurular yapmakta, onların yaptıkları yardımları da topluma duyurarak daha fazla gönüllünün katıımı için toplumu etkilemeye çalışmaktadır. Sözcü olmanın dışında elçi olarak da bağış toplama etkinliklerinde yer alsa da özellikle kurucusu olduğu Ahbap Derneği ekseninde aktivist çalışmalarına yer vermesi sözcü kimliği ile daha fazla uyuşmaktadır. Haluk Levent'in sanatçı kimliğini öne çıkardığı paylaşımlarında da toplumsal konularla ilgisini tamamen göz ardı etmediği görülmektedir. Bu bağlamda 'Sözcü' kimliğinin, aktivist olsun veya olmasın tüm Twitter kullanımına yansıdığı anlaşılmaktadır. Ayrıca yaptığı paylaşımlarda Ahbap Platformu ile kendi hesabı üzerinden etkileşim kurması gönüllüleri motive etmeye, derneğe yönelik farkındalığı arttırmaya yönelik çaba olarak yorumlanabilmektedir. Özellikle gönüllülerle ve ihtiyaç sahipleriyle samimi bir aile bağı kurarak Twitter'ı da bu bağı yansıtmak üzere değerlendirmesi takipçilerle etkileşim kurmasına yardımcı olmaktadır. Literatürde de belirtildiği üzere ünlü aktizminde ünlü, amaç, hedef kitle arasında bir bağ kurulmuş olması önem taşımaktadır (Ellcessor, 2018, pp. 266-267). Literatürde ünlü ve hayranlar arasında bir toplumsal mesafe olduğu (Rojek, 2001, p. 12) yardım çalışmaları ile aktivist kimliği kazanan ünlüler ile hayranlar arasında yakınlığın arttığı (Fuqua, 2011, p.193) ifade edilmektedir. Bu bağlamda Haluk Levent'in ünlü aktivizmi çerçevesinde Twitter kullanımının, literatürde de önerildiği biçimde gerçekleştiği anlaşılmaktadır.

Bu çalışmanın, ünlü ve dijital aktivizm ekseninde gerçekleştirilen çalışmaların kısıtlı olması nedeniyle alana katkı sağlayacağı düşünülmektedir. Illeride gerçekleştirilecek çalışmalar için içerik analizinin yanı sıra ünlülerle derinlemesine görüşme ve gönüllülerle anket çalışması yapılarak ünlü aktivizminin etkilerinin irdelenmesi önerilmektedir.

Finansal Destek: Yazarlar bu çalışma için finansal destek almamışlardır.

\section{KAYNAKLAR}

Activism. (n.d.). Oxford English Dictionary. Retrieved from https://en.oxforddictionaries.com/definition/activism Andersson, J. (2007). Pop-culture icons as agents of change? The roles and functions of celebrity activist in peace-and development related global issues. Vaxjö Universitet School of Social Sciences Peace and Development Studies Master Thesis.

Bennett, L. (2013). 'If we stick together we can do anything': Lady Gaga fandom, philanthropy and activism through social media. Celebrity Studies, 5(1-2), 138-152. http://dx.doi.org/10.1080/19392397.2013.813778 
Bishop, M., \& Green, M. (2008) Philanthrocapitalism: How the Rich Can Save the World, New York, USA: Bloomsbury Press. Budabin, A. C. (2015). Celebrities as norm entrepreneurs in international politics: Mia Farrow and the 'Genocide Olympics' campaign, Celebrity Studies, 6(4), 399-413. http://dx.doi.org/10.1080/19392397.2015.1087206

Buente, W., \& Rathnayake, C. (2016). \#WeAreManuaKea: Celebrity involvement in a protest movement, IConference 2016 Proceedings. http://dx.doi.org/10.9776/16311

Bulck, H., \& Panis, K. (2010). Michael as he is not remembered: Jackson's 'forgotten' celebrity activism, Celebrity Studies, 1(2), 242-244. http://dx.doi.org/10.1080/19392397.2010.482308

Cammaerts, B. (2007). Activism and media. In B. Cammaerts \& N. Carpentier (Eds.), Reclaiming The Media (pp. 217-224). Chicago, USA: Intellect Books.

Cammaerts, B. (2015). Social media and activism In Mansell, R., \& Hwa. P. (Eds.), The international encyclopedia of digital communication and society (pp. 1027-1034). Oxford, UK: Wiley-Blackwell.

Considine, S. (2003). Homepage: Internet activism and women, Field: A Free Journal for Architecture, 3(1), 133141.

Cooper, A. (2008). Celebrity diplomacy. Colorado, USA: Paradigm Publishers.

Denning, D. E. (2001). Activism, hacktivism, and cyberterrorism: The internet as a tool for influencing foreign policy In J. Arquilla \& D. F. Ronfeldt (Eds.), Networks and netwars: The future of terror, crime, and militancy (pp. 239-288).

Derneğin Amacı. (2018). Ahbap Platformu. Retrieved from https://ahbap.org/.

Duvall, S. S. (2015). Masculine interventions and transnational celebrity activism in the aftermath of the 2010 earthquake in Haiti, Celebrity Studies, 6(4), 583-600. http://dx.doi.org/10.1080/19392397.2015.1037779

Duvall, S. S. \& Heckemeyer, N. (2018) \#BlackLivesMatter: Black celebrity hashtag activism and the discursive formation of a social movement, Celebrity Studies, 9(3), 391-408. http://dx.doi.org/10.1080/19392397.2018.1440247

Ellcessor, E. (2018). "One tweet to make so much noise": Connected celebrity activism in the case of Marlee Matlin, New Media \& Society, 20(1), 255-271.

Einspanner J., Dang-Anh, \& Thimm, C., (2016). Twitter verilerinin bilgisayar destekli içerik analizi (E. Özbatur, Trans.). In K. Weller, A. Burns, J. Burgess, M. Mahrt, \& C. Puschmann (Eds.), Twitter ve toplum (pp. 136-145). İstanbul, Turkey: Kafka Epsilon Yayıncılık.

Franklyn, A. (2016). Celebrity feminism: exploring the influence of a famous feminist (Bachelor of arts dissertation, Oklahoma State University, Oklahoma). Retrieved from https://shareok.org/bitstream/handle/11244/49074/ Franklyn_okstate_0664M_14827.pdf

Fuqua, J. V. (2011) Brand Pitt: celebrity activism and the make it right foundation in post-Katrina New Orleans. Celebrity Studies, 2(2), 192-208. http://dx.doi.org/10.1080/19392397.2011.574872

Hanna, P., Kantenbacher, J., Cohen, S., \& Gössling, S. (2018). Role model advocacy for sustainable transport. Transportation Research Part D: Transport and Environment, 61, 373-382.

Hart, P. T., \& Tindall, K. (2009). Leadership by the famous: Celebrity as political capital, In J. Kane, H. Patapan, P. 't Hart (Eds.), Dispersed Leadership in Democracies, Oxford, UK: Oxford University Press 
Hassid, J., \& Jeffreys, E. (2015). Doing good or doing nothing? Celebrity, media and philanthropy in China. Third World Quarterly, 36(1), 75-93. http://dx.doi.org/10.1080/01436597.2015.976019

Huddart, S. (2005). Do we need another hero? Understanding celebrities' roles in advancing social causes. Montreal, Canada: McGill University.

Huijer, H., \& Tay, J. (2011). Can celebrity save diplomacy? Appropriating Wisdom through 'The Elders'. In L. Tsaliki,

C. A. Frangonikolopoulos, \& A. Huliaras (Eds.), Transnational celebrity activism in global politics: Changing the world? (pp. 105-120). Chicago, USA: Intellect Books.

Huliara, A., \& Tzifakis, N. (2010) Celebrity activism in international relations: In search of a framework for analysis. Global Society, 24(2), 255-274. http://dx.doi.org/10.1080/13600821003626567

Hunting, K., \& Hinck, A. (2017). "I'll see you in Mystic Falls": intimacy, feelings, and public issues in lan Somerhalder's celebrity activism. Critical Studies in Media Communication, 34(5), 432-448.

Jampolsky, J. A. (2012). 'Activism is the new black! Demonstrating the benefits of international celebrity activism through James Cameron's campaign against the Belo Monte Dam. Colorado Journal of International Environmental Law and Policy, 23(1), 227-256.

Jeffreys, E., \& Allatson, P. (2015). Celebrity philanthropy: An introduction. In E. Jeffreys, \& P. Allatson (Eds.), Celebrity philanthropy (pp. 1-16). Bristol, UK: Intellect Books.

Jeffreys, E. (2016). Translocal celebrity activism: shark-protection campaigns in mainland China, Environmental Communication, 10(6), 763-776. http://dx.doi.org/10.1080/17524032.2016.1198822

Jeffreys, E., \& Xu, J. (2017). Celebrity-inspired, fan-driven: Doing philanthropy through social media in mainland China, Asian Studies Review, 41(2), 244-262. http://dx.doi.org/10.1080/10357823.2017.1294145

Kvansay, L., Paytan, F.C., \& Hales, K.D. (2010). Social activism in the 'Blackosphere': The jena 6 case. In J. Park \& E. Abels (Eds.), Interpersonal and social patterns in communication technologies: discourse norms, language structures and cultural variables (pp. 18-31). Pennsylvania, USA: IGI Global.

Lawson, C. E. (2018). Platform feminism: Celebrity culture and activism in the digital age (Doctoral dissertation, University of Michigan, Michigan).

Marwick, A. \& Boyd, D. (2011). To see and be seen: Celebrity practice on Twitter. Convergence: The International Journal of Research into New Media Technologies, 17(2), 139-158. http://dx.doi.org/10.1177/1354856510394539

McCracken, G. (1989). Who is the celebrity endorser? Cultural foundations of the endorsement process. Journal of Consumer Research, 16(3), 310-321.

Milner, M. (2010). Is celebrity a new kind of status system? Society, 47(5), 379-387.

Rojek, C. (2001). Celebrity. London, UK: Reaktion Books.

Rotman, D., Veiweg, S., Yardi, S., Chi, E. H., Preece, J., Shneiderman, B., Pirolli, P. \& Glaisyer, T. (2011). From slacktivism to activism: Participatory culture in the age of social media. Proceedings of the International Conference on Human Factors in Computing Systems, CHI 2011, Vancouver, BC, Canada.

Saxton, G., \& Wang, L. (2013). The social network effect: The determinants of giving through social media. Nonprofit and Voluntary Sector Quarterly, 43(5), 850-860. 
Scott, V. (2011) Is Celebrity activism a boom-time bubble that is facing deflation? International Journal of Media and Cultural Politics, 7(1), 77-84.

Senft, T. (2008). Camgirls: Celebrity and community in the age of social networks. New York, USA: Peter Lang.

Sivitanides, M., \& Shah, V.(2011). The era of digital activism. Conference for Information Systems Applied Research Proceedings, USA: Wilmington North Carolina.

Street, J. (2004). Celebrity politicians: popular culture and political representation. British Journal of Politics and International Relations, 6(4), 435-452.

Turner, G. (2013). Understanding celebrity (2nd ed.). Thousand Oaks, CA: Sage Publications.

Tüfekçi, Z. (2013). "Not this one": Social movements, the attention economy, and microcelebrity networked activism. American Behavioral Scientist, 57(7), 848-870. http://dx.doi.org/10.1177/0002764213479369

User Statistics Table for Haluk_Levent. (2018). Social Blade. Retrieved from https://socialblade.com/twitter/user/ haluk_levent/monthly.

Van Laer, J. \& Van Aelst, P. (2010). Internet and Social Movement Action Repertoires, Information, Communication \& Society, 13(8), 1146-1171.

Wheeler, M. (2011). Celebrity diplomacy: United nations' goodwill ambassadors and messengers of peace. Celebrity Studies, 2(1), 6-18.

Yang, Y., Zhou, W., \& Zhang, D. (2018). Celebrity philanthropy in China: An analysis of network effect on philanthropic engagement. VOLUNTAS: International journal of voluntary and nonprofit organizations, 1-16. http://dx.doi.org/10.1007/s11266-018-9997-7

Yegen, C. (2014a). Bir dijital aktivizm biçimi olarak slaktivizm: Change.org örneği, Karadeniz Teknik Üniversitesi İletişim Araştırmaları Dergisi, 8, 84-108.

Yegen, C. (2014b). Dijital aktivizmin bir türü olarak hacktivizm ve"redhack", E-journal of Intermedia, 1(1), $118-132$.

Yılmaz, B., Dündar, G., \& Oskay, T. (2015). Dijital ortamda aktivizm: Online imza kampanyalarına katılım davranışlarının incelenmesi (Kocaeli Üniversitesi iletişim fakültesi öğrencileri üzerine bir araştırma). E-journal of Intermedia, 2(2), 481-504. 


\section{TABLOLAR VE ŞEKILLER}

Tablo 1: Gönderilerin Aldığı Beğeni, Yorum ve Retweet Dağılımı Tablosu

\begin{tabular}{lcclccccc}
\hline \multicolumn{1}{c}{ Beğeni } & Frekans & $\%$ & Yorum & Frekans & $\%$ & Retweet & Frekans & $\%$ \\
\hline $1-1000$ & 244 & 47,6 & $1-50$ & 375 & 73,0 & $1-100$ & 334 & 65,1 \\
$1001-2000$ & 121 & 23,6 & $51-100$ & 50 & 9,7 & $101-500$ & 125 & 24,4 \\
$2001-3000$ & 41 & 8,0 & $101-150$ & 28 & 5,5 & $501-1000$ & 30 & 5,8 \\
$3001-4000$ & 27 & 5,3 & $151-200$ & 18 & 3,5 & $1001-1500$ & 7 & 1,4 \\
$4001-5000$ & 14 & 2,7 & $201-250$ & 11 & 2,1 & $1501-2000$ & 2 &, 4 \\
$5001-6000$ & 9 & 1,8 & $251-300$ & 4 &, 8 & $2001-2500$ & 2 &, 4 \\
6001-üstü & 57 & 11,1 & $301-350$ & 5 & 1,0 & $2500-3000$ & 4 &, 8 \\
& & & $350-u ̈ s t u ̈$ & 22 & 4,3 & $3001-u ̈ s t u ̈$ & 9 & 1,8 \\
Toplam & $\mathbf{5 1 3}$ & $\mathbf{1 0 0}$ & Toplam & $\mathbf{5 1 3}$ & $\mathbf{1 0 0}$ & Toplam & $\mathbf{5 1 3}$ & $\mathbf{1 0 0}$ \\
\hline
\end{tabular}

Tablo 2: Gönderi Konuları ve Beğeni Oranları İlișkisi Tablosu

\begin{tabular}{|c|c|c|c|c|c|c|c|c|c|}
\hline \multicolumn{2}{|c|}{ Beğeni/Konu } & $1-1000$ & 1001- & 2001- & 3001- & 4001- & 5001- & 6001- & Toplam \\
\hline \multirow{3}{*}{ Sağlık } & Frekans & 98 & 30 & 11 & 6 & 2 & 0 & 7 & 154 \\
\hline & \%Paylașım & 63,6 & 19,5 & 7,1 & 3,9 & 1,3 & 0 & 4,5 & 100 \\
\hline & \%Toplam & 19,1 & 5,8 & 2,1 & 1,2 & 0,4 & 0 & 1,4 & 30 \\
\hline \multirow{3}{*}{ Eğitim } & Frekans & 5 & 3 & 0 & 0 & 1 & 0 & 0 & 9 \\
\hline & \%Paylaşım & 55,6 & 33,3 & 0 & 0 & 11,1 & 0 & 0 & 100 \\
\hline & \%Toplam & 1 & 0,6 & 0 & 0 & 0,2 & 0 & 0 & 1,8 \\
\hline \multirow{3}{*}{ Yoksulluk } & Frekans & 28 & 15 & 1 & 0 & 0 & 0 & 0 & 44 \\
\hline & \%Paylaşım & 63,6 & 34,1 & 2,3 & 0 & 0 & 0 & 0 & 100 \\
\hline & \%Toplam & 5,5 & 2,9 & 0,2 & 0 & 0 & 0 & 0 & 8,6 \\
\hline \multirow{3}{*}{$\begin{array}{c}\text { Madde } \\
\text { Bağımlılığı }\end{array}$} & Frekans & 0 & 1 & 0 & 0 & 1 & 0 & 0 & 2 \\
\hline & \%Paylaşım & 0 & 50 & 0 & 0 & 50,0 & 0 & 0 & 100 \\
\hline & \%Toplam & 0 & 0,2 & 0 & 0 & 0,2 & 0 & 0 & 0,4 \\
\hline \multirow{3}{*}{ Bağış ve Burs } & Frekans & 61 & 32 & 10 & 2 & 0 & 1 & 5 & 111 \\
\hline & \%Paylaşım & 55 & 28,8 & 9 & 1,8 & 0 & 0,9 & 4,5 & 100 \\
\hline & \%Toplam & 11,9 & 6,2 & 1,9 & 0,4 & 0 & 0,2 & 1 & 21,6 \\
\hline \multirow{3}{*}{$\begin{array}{c}\text { Sanata } \\
\text { Duyarlılık }\end{array}$} & Frekans & 1 & 3 & 0 & 0 & 0 & 0 & 0 & 4 \\
\hline & \%Paylașım & 25 & 75 & 0 & 0 & 0 & 0 & 0 & 100 \\
\hline & \%Toplam & 0,2 & 0,6 & 0 & 0 & 0 & 0 & 0 & 0,8 \\
\hline \multirow{3}{*}{ Diğer } & Frekans & 32 & 18 & 10 & 14 & 4 & 3 & 12 & 93 \\
\hline & \%Paylaşım & 34,4 & 19,4 & 10,8 & 15,1 & 4,3 & 3,2 & 12,9 & 100 \\
\hline & \%Toplam & 6,2 & 3,5 & 1,9 & 2,7 & 0,8 & 0,6 & 2,3 & 18,1 \\
\hline \multirow{3}{*}{ Çevre } & Frekans & 4 & 4 & 0 & 1 & 0 & 1 & 2 & 12 \\
\hline & \%Paylaşım & 33,3 & 33,3 & 0 & 8,3 & 0 & 8,3 & 16,7 & 100 \\
\hline & \%Toplam & 0,8 & 0,8 & 0 & 0,2 & 0 & 0,2 & 0,4 & 2,3 \\
\hline \multirow{3}{*}{$\begin{array}{l}\text { Hayvan } \\
\text { Hakları }\end{array}$} & Frekans & 6 & 2 & 0 & 0 & 1 & 0 & 0 & 9 \\
\hline & \%Paylaşım & 66,7 & 22,2 & 0 & 0 & 11,1 & 0 & 0 & 100 \\
\hline & \%Toplam & 1,2 & 0,4 & 0 & 0 & 0,2 & 0 & 0 & 1,8 \\
\hline \multirow{3}{*}{$\begin{array}{l}\text { Sanatçı } \\
\text { Kimliği }\end{array}$} & Frekans & 1 & 10 & 9 & 3 & 5 & 4 & 26 & 58 \\
\hline & \%Paylașım & 1,7 & 17,2 & 15,5 & 5,2 & 8,6 & 6,9 & 44,8 & 100 \\
\hline & \%Toplam & 0,2 & 1,9 & 1,8 & 0,6 & 1 & 0,8 & 5,1 & 11,3 \\
\hline \multirow{3}{*}{$\begin{array}{l}\text { Çocuk } \\
\text { İstismarı }\end{array}$} & Frekans & 8 & 3 & 0 & 1 & 0 & 0 & 3 & 15 \\
\hline & \%Paylaşım & 53,3 & 20,0 & 0 & 6,7 & 0 & 0 & 20 & 100 \\
\hline & \%Toplam & 1,6 & 0,6 & 0 & 0,2 & 0 & 0 & 0,6 & 2,9 \\
\hline \multirow{3}{*}{ Şiddet } & Frekans & 0 & 0 & 0 & 0 & 0 & 0 & 2 & 2 \\
\hline & \%Paylaşım & 0 & 0 & 0 & 0 & 0 & 0 & 100 & 100 \\
\hline & \%Toplam & 0 & 0 & 0 & 0 & 0 & 0 & 0,4 & 0,4 \\
\hline \multirow{3}{*}{ Toplam } & Frekans & 244 & 121 & 41 & 27 & 14 & 9 & 57 & 513 \\
\hline & \%Paylaşım & 47,6 & 23,6 & 8 & 5,3 & 2,7 & 1,8 & 11,1 & 100 \\
\hline & \%Toplam & 47,6 & 23,6 & 8 & 5,3 & 2,7 & 1,8 & 11,1 & 100 \\
\hline
\end{tabular}


Tablo 3: Tweetlerin Metin Tonu ve Aktivist İçerik Dağılımı Tablosu

\begin{tabular}{|c|c|c|c|c|}
\hline & & \multicolumn{2}{|c|}{ Aktivist İçerik } & \multirow[b]{2}{*}{ Toplam } \\
\hline & & Evet & Hayır & \\
\hline \multirow{3}{*}{ Samimi } & Frekans & 384 & 94 & 478 \\
\hline & $\%$ Metin Tonu & 80,3 & 19,7 & 100 \\
\hline & \% Toplam & 74,9 & 18,3 & 93,2 \\
\hline \multirow{3}{*}{ Ciddi } & Frekans & 7 & 0 & 7 \\
\hline & $\%$ Metin Tonu & 100 & $0 \%$ & 100 \\
\hline & \% Toplam & 1,4 & 0 & 1,4 \\
\hline \multirow{3}{*}{ Mizahi } & Frekans & 0 & 28 & 28 \\
\hline & $\%$ Metin Tonu & 0 & 100 & 100 \\
\hline & \% Toplam & 0 & 5,5 & 5,5 \\
\hline \multirow{3}{*}{ Toplam } & Frekans & 391 & 122 & 513 \\
\hline & $\%$ Metin Tonu & 76,2 & 23,8 & 100 \\
\hline & \% Toplam & 76,2 & 23,8 & 100 \\
\hline
\end{tabular}

\section{Ek: İçerik Analizi Değişken Listesi}

İçerik analizi uygulanan tweetlerin tarih aralığı: 15 Ekim 2018 - 15 Aralık 2018

\section{Haluk Levent'in Resmi Twitter Hesabının Temel Özellikleri}

- Tweet Sayısı: Haluk Levent'in Twitter hesabında attığı toplam tweet sayısı

- Takip Edilen: Haluk Levent'in Twitter hesabında takip ettiği kullanıcı sayısı

- Takipçi: Haluk Levent'in Twitter hesabını takip eden kullanıcı sayısı

- Beğeni: Haluk Levent'in beğendiği tweet sayısı

\section{Haluk Levent'in Twitter gönderilerinin aldığı etkileşim}

- Beğeni: Haluk Levent'in tweetlerine diğer kullanıcılardan gelen tweet beğenisi

- Yorum: Haluk Levent'in tweetlerine diğer kullanıcılardan gelen yorumlar

- Retweet: Haluk Levent'in tweetlerine diğer kullanıcılardan gelen retweet

\section{Haluk Levent'in Twitter Gönderilerinde Görsel Bulunma Durumu}

- Evet: Tweette görsel bulunması

- Hayır: Tweette görsel bulunmaması 


\section{Haluk Levent'in Retweetlerinde Haydi Ahbap ve Ahbap Platformu Hesaplarından Retweet Yapma Durumu}

- Evet: Haydi Ahbap ve Ahbap Platformu hesaplarından yapılan retweetler

- Hayır: Farklı kullanıcılardan retweetler

- Retweet Değil: Haluk Levent'in kendi hesabından gönderdiği tweetler

\section{Haluk Levent'in Tweetlerinde Mention özelliği ile Haydi Ahbap ve Ahbap Platformu Hesaplarını Etiketlemesi}

- Evet: Haydi Ahbap ve Ahbap Platformu Hesaplarının mention özelliği ile etiketlendiği tweetler

- Hayır: Diğer tweetler

\section{Haluk Levent'in Twitter Hesabındaki Gönderi Konuları}

- Sağlık: Hastalık, tedavi, ameliyat, ilaç veya donör arayışı içerikleri vb.

- Bağış ve Burs: Maddi durumu yeterli olmayan kişilerin eğitim giderlerini, eksiklerini karşılamaya yönelik bağış ve burs kampanyalarına, yardımlarına ilişkin içerikler

- Sanatçı Kimliği: Haluk Levent'in konser, albüm, müzik klibi gibi çalışmalarına ilişkin içerikler

- Yoksulluk: Maddi durumu yetersiz kişilerin gereksinimlerinin karşılanmasına ilişkin içerikler

- Çocuk İstismarı: Çocuklara yönelik kötü davranışlara gösterilen tepkilere ilişkin içerikleri

- Çevre: Orman alanlarına zarar verilmesine karşı kampanyalara, ağaçlandırma kampanyalarına iliş̧in içerikler

- Eğitim: Çocukların eğitim hakları, maddi yetersizlikler nedeniyle eğitim alamamasına ilişkin içerikler

- Hayvan Hakları: Hayvanların korunması, hayvanlara yönelik şiddet, hayvanların tedavi ettirilmesine ilişkin içerikler

- Şiddet: Bireylere yönelik fiziksel ve psikolojik şiddete ilişkin içerikler

- Sanata Duyarlılık: Sanata yönelik olumlu bakış açısını destekleyici içerikler

- Madde Bağımlılığı: Madde bağımlıığına yönelik tepki ve sonuçlarını içeren içerikler

- Diğer: Belirtilen kategoriler dışında yer alan içerikler 


\section{Haluk Levent'in Twitter Gönderilerinde Metin Tonu}

- Samimi: Gönderide yer verilen konuya bağlı olarak daha arkadaşça olarak tanımlanabilecek sohbet havası bulunmaktadır.

- Ciddi: Gönderide yer verilen konuya bağlı olarak resmi ve mesafeli bir dil kullanılmaktadır.

- Mizahi: Gönderide yer verilen konuya bağlı olarak neşeli ve esprili bir dil kullanılmaktadır.

\section{Haluk Levent'in Twitter Gönderilerinde Ünlü ve Sivil Toplum Etkileşimi Modeli}

\section{Kategorileri}

- Koruyucu: Haluk Levent'in Twitter hesabında ünlü ve sivil toplum etkileşimi modeli kategorilerinden olan "koruyucu" kategorisinin yansıtıldığı tweetler

- Sözcü: Haluk Levent'in Twitter hesabında ünlü ve sivil toplum etkileşimi modeli kategorilerinden olan "sözcü" kategorisinin yansıtıldığı tweetler

- Elçi/Yazar: Haluk Levent'in Twitter hesabında ünlü ve sivil toplum etkileşimi modeli kategorilerinden olan "elçi/yazar" kategorisinin yansıtıldığı tweetler

- Vizyoner Lider: Haluk Levent'in Twitter hesabında ünlü ve sivil toplum etkileşimi modeli kategorilerinden olan "vizyoner lider" kategorisinin yansıtıldığı tweetler

- Diğer: Ünlü ve sivil toplum etkileşimi modeli kategorilerinin dışında kalan tweetler 
